\title{
Pontibacillus yanchengensis sp. nov., a moderately halophilic bacterium isolated from salt field soil
}

\author{
Correspondence \\ Gejiao Wang \\ gejiaow@yahoo.com.cn or \\ gejiao@mail.hzau.edu.cn
}

\author{
Yan Yang, Zhengzhong Zou, Minyan He and Gejiao Wang \\ State Key Laboratory of Agricultural Microbiology, College of Life Science and Technology, \\ Huazhong Agricultural University, Wuhan 430070, PR China
}

\begin{abstract}
A Gram-positive-staining, aerobic, moderately halophilic bacterium, designated strain $\mathrm{Y}_{3} 2^{\top}$, was isolated from subsurface soil of the Sanwei salt field, Yancheng, Jiangsu province, South-east China. The cell-wall peptidoglycan type of strain $\mathrm{Y}_{32}{ }^{\top}$ was meso-diaminopimelic acid.

The menaquinone was menaquinone-7 (MK-7). The major fatty acids were anteiso- $\mathrm{C}_{15: 0}$ and iso- $\mathrm{C}_{15: 0}$ and the DNA G+C content of strain $\mathrm{Y}_{32}{ }^{\top}$ was $40.3 \mathrm{~mol} \%$. Phylogenetic analysis based on 16S rRNA gene sequences showed that strain $\mathrm{Y}_{3} 2^{\top}$ was closely related to the type strains of the genus Pontibacillus. The $16 \mathrm{~S}$ rRNA gene sequence similarities of strain $\mathrm{Y} 32^{\top}$ with the type strains of species of the genus Pontibacillus were $97.8 \%$ (Pontibacillus marinus KCTC

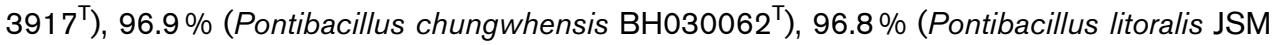
$072002^{\top}$ ) and $96.0 \%$ (Pontibacillus halophilus JSM $076056^{\top}$ ). DNA-DNA relatedness between strain $\mathrm{Y}_{32}{ }^{\top}$ and $P$. marinus KCTC $3917^{\top}$ was $42 \%$. On the basis of phenotypic, chemotaxonomic and phylogenetic evidences, strain $\mathrm{Y} 32^{\top}$ was found to be affiliated to the genus Pontibacillus, but was clearly differentiated from other members of this genus. Strain $\mathrm{Y} 32^{\top}$ represents a novel member of the genus, for which the name Pontibacillus yanchengensis sp. nov. is proposed. The type strain is $\mathrm{Y}^{2} 2^{\top}\left(=\right.$ CGMCC $1.10680^{\top}=$ CCTCC AB209311 ${ }^{\top}=$ NRRL B-59408 $\left.{ }^{\top}\right)$.
\end{abstract}

Moderately halophilic bacteria that grow optimally in media containing $1-15 \%(\mathrm{w} / \mathrm{v}) \mathrm{NaCl}$ constitute a heterogeneous physiological group of micro-organisms which belong to many different genera (Ventosa et al., 1998). Spore-forming moderately halophilic Gram-positive rods isolated from marine or hypersaline environments were formerly placed in the genus Bacillus. Through chemotaxonomic and molecular analyses, several phylogenetically distinct lineages in the genus Bacillus have been revealed and many spore-forming bacteria have been placed into separate genera (Ash et al., 1991; Nielsen et al., 1994). In 2005, Lim et al. (2005a) proposed the genus Pontibacillus, members of which were described as Gram-positive, sporeforming, rod-shaped, strictly aerobic and moderately halophilic and containing MK-7 as the major isoprenoid quinone and possessing Al $\gamma$-type meso-diaminopimelic acid in the cell wall (Lim et al., 2005a). Recently, Chen et al. (2010) proposed the species Pontibacillus litoralis and found that it differed from the original genus description as presented by Lim et al. (2005a) by the ability to perform facultative anaerobiosis and by having creamy-white pigmentation. Thus, the genus description was emended to remove strictly aerobic growth as a characteristic of the

The GenBank/EMBL/DDBJ accession number for the 16S rRNA gene sequence of strain $Y 32^{\top}$ is EF533969.

Three supplementary figures are available with the online version of this paper. genus. At the time of writing, there are four recognized members of this genus, Pontibacillus chungwhensis (Lim et al., 2005a), Pontibacillus marinus (Lim et al., 2005b), Pontibacillus halophilus (Chen et al., 2009) and Pontibacillus litoralis (Chen et al., 2010). These species were isolated from a solar saltern on the Yellow Sea ( $P$. chungwhensis and $P$. marinus), a sea urchin ( $P$. halophilus) and a sea anemone (P. litoralis). In this study, a Gram-positive-staining, moderately halophilic bacterium, strain $\mathrm{Y} 32^{\mathrm{T}}$, was isolated from the soil of a salt field. According to the minimal standards for describing new taxa of aerobic, endospore-forming bacteria (Logan et al., 2009), and on the basis of morphological, physiological, chemotaxonomic and phylogenetic characteristics, it is concluded that strain $\mathrm{Y} 32^{\mathrm{T}}$ represents a new member of the genus Pontibacillus.

Strain $\mathrm{Y} 32^{\mathrm{T}}$ was isolated from a mixed subsurface soil sample $(5-15 \mathrm{~cm}$ deep) from the Sanwei salt field, which is located near the Yellow Sea in Yancheng City $\left(32^{\circ} 23^{\prime} 43^{\prime \prime} \mathrm{N}, 120^{\circ} 0^{\prime} 34^{\prime \prime} \mathrm{E}\right.$, with an annual mean temperature of $14{ }^{\circ} \mathrm{C}$ ), Jiangsu Province, South-east China. This salt field belongs to the Sanwei salt factory, one of the largest salt production factories in China, which produces salt from seawater. The texture of the soil sample was clay; the $\mathrm{pH}$ was 7.95; and the $\mathrm{Na}^{+}, \mathrm{K}^{+}, \mathrm{Mg}^{2+}$ and organic matter contents were $8.13 \mathrm{~g} \mathrm{~kg}^{-1}, 1.22 \mathrm{~g} \mathrm{~kg}^{-1}$, $1.44 \mathrm{mg} \mathrm{kg}^{-1}$ and $0.80 \%$, respectively. For strain isolation, a $10 \mathrm{~g}$ filtered soil sample was added to $90 \mathrm{ml}$ sterilized 
HGM liquid medium (Fairley et al., 2002) and incubated at $37^{\circ} \mathrm{C}$ for 30 min with shaking at 160 r.p.m. An aliquot of the suspension was diluted with $10 \%(\mathrm{w} / \mathrm{v}) \mathrm{NaCl}$ solution and streaked onto HGM agar plates that were then incubated at $37^{\circ} \mathrm{C}$ for one week. About $10^{6}$ c.f.u. $g^{-1}$ colonies were obtained. After several rounds of restreaking, single colonies were used for DNA isolation and 16S rRNA gene identification. By analysing 50 colonies, six halophilic bacterial strains were obtained that were pre-identified as belonging to the genera Bacillus (GenBank accession no. EF533965), Halobacillus (EF533963 and EF533970), Halomonas (EF533962 and EF533966) and Pontibacillus (Y32 ${ }^{\mathrm{T}}$, EF533969). Strain $\mathrm{Y}_{32}{ }^{\mathrm{T}}$ was considered to represent a novel species of the genus Pontibacillus and was chosen for further study. Strain $\mathrm{Y} 32^{\mathrm{T}}$ was routinely grown aerobically on marine agar 2216 (MA medium, pH 7.5, Difco) supplemented with $5 \%(\mathrm{w} / \mathrm{v}) \mathrm{NaCl}$ for 2 days at $37^{\circ} \mathrm{C}$, except where mentioned otherwise. Anaerobic growth was determined by incubation in an anaerobic chamber (Mitsubishi Gas Chemical Co. Inc.) at $37^{\circ} \mathrm{C}$ on the same medium.

The morphology of cells was observed using light and transmission electron microscopes. Gram staining was determined using the method described by Dussault (1955). Endospores and flagella were stained according to the methods of Schaeffer-Fulton and Leifsson (Smibert \& Krieg, 1994), respectively. The temperature for growth was tested at different temperatures $\left(4-55^{\circ} \mathrm{C}\right)$ on MA medium supplemented with $5 \%(\mathrm{w} / \mathrm{v}) \mathrm{NaCl}$. The $\mathrm{pH}$ range for growth was determined in filter-sterilized MA medium supplemented with $5 \% \mathrm{NaCl}$ by adding acetic acid/sodium acetate ( $\mathrm{pH}$ 4.0-4.5), MES ( $\mathrm{pH}$ 5.0-6.0, $10 \mathrm{mM}$ ), PIPES (pH 6.5-7.0, $10 \mathrm{mM})$, Tris/HCl ( $\mathrm{pH} 7.5-$ $9.0,10 \mathrm{mM}$ ) and adjusted with $\mathrm{NaOH}$ or $\mathrm{HCl}$. Requirement of and tolerance to $\mathrm{NaCl}$ were determined in nutrient broth supplemented with modified artificial seawater containing $0-30 \%(\mathrm{w} / \mathrm{v}) \mathrm{NaCl}$ ( $\mathrm{Lim}$ et al., 2005a). Growth was monitored by measuring the optical density at $600 \mathrm{~nm}$. Hydrolysis of casein, gelatin, xanthine, hypoxanthine, urea, starch, Tween 80 , L-tyrosine and urea was performed as described by Cowan \& Steel (1965). Acid production from carbohydrates was determined as described by Leifson (1963). Nitrate and nitrite reduction were tested by the method described by Lányí (1987). Methyl red and Voges-Proskauer tests, $\mathrm{H}_{2} \mathrm{~S}$ and indole production and determination of aesculin hydrolysis were performed as recommended by Smibert \& Krieg (1994). The oxidation/fermentation of glucose was determined according to the method of Mata et al. (2002). Catalase and oxidase activities were determined by the method described by Lim et al. (2005a). Other enzyme activities were tested using API ZYM strips (bioMérieux) according to the manufacturer's instructions except for the suspension medium being supplemented with $4 \%(\mathrm{w} / \mathrm{v}) \mathrm{NaCl}$. The experiments were performed using $P$. marinus KCTC $3917^{\mathrm{T}}$, P. chungwhensis KCTC $3890^{\mathrm{T}}$, P. litoralis KCTC $13237^{\mathrm{T}}$ and $P$. halophilus KCTC $13190^{\mathrm{T}}$ as reference strains.
The utilization of sole carbon and nitrogen sources was analysed using a traditional method (Ventosa et al., 1982) and API 32 GN strips (bioMérieux).

Genomic DNA was isolated from the novel strain using a previously described procedure (Cashion et al., 1977). The 16S rRNA gene sequence was amplified by PCR with universal primers Uni-27F and Uni-1492R (Wilson et al., 1990). The PCR product was ligated into a pGEM-T vector (Promega). DNA sequencing was performed by Beijing Genomics Institute (China). The resulting 16S rRNA gene sequence was compared with the sequences from the NCBI GenBank database to determine which reference strains were most closely related to strain $\mathrm{Y}_{3} 2^{\mathrm{T}}$. The similarities were calculated using the NCBI alignment and EzTaxon programs (Chun et al., 2007). Multiple alignments of sequences determined in this study together with reference sequences obtained from the databases and calculations of levels of sequence similarity were carried out using CLUSTAL $\mathrm{w}$ (Thompson et al., 1994). Neighbour-joining and maximum-parsimony trees were constructed using MEGA 4.0 (Tamura et al., 2007), and a maximum-likelihood tree was generated using the PHYLIP package (Felsenstein, 2002). The confidence values for the branches of phylogenetic trees were determined using bootstrap analyses based on 1000 replications. DNA-DNA hybridization was performed by the thermal denaturation and renaturation method (Huß et al., 1983). DNA was sheared by sonication to generate fragments of $2-5 \times 10^{5} \mathrm{Da}$ and renaturation was performed in $2 \times$ SSC at the optimum temperature.

The DNA G+C content was determined by HPLC according to the method of Tamaoka \& Komagata (1984). Analysis of menaquinones was performed by HPLC as described by Xie \& Yokota (2003). Quinones were extracted with chloroform/methanol $(2: 1, \mathrm{v} / \mathrm{v})$, evaporated in a vacuum and separated by TLC on silicagel $\mathrm{F}_{254}$ plates with hexane/ethyl ether $(85: 15)$ as the solvent system. Quinone components were eluted with the mobile phase of methanol and isopropyl ether $(4: 1, \mathrm{v} / \mathrm{v})$ by HPLC. For whole-cell fatty acid analysis, strain $\mathrm{Y} 32^{\mathrm{T}}$ and the four reference strains were grown at $35{ }^{\circ} \mathrm{C}$ for $48 \mathrm{~h}$ on MA supplemented with $3 \%(\mathrm{w} / \mathrm{v}) \mathrm{NaCl}$ and analysed by GC (6890; Hewlett Packard) according to the instructions of the Sherlock Microbial Identification System (MIDI). Cell walls were purified and analysed using the TLC protocol (Lechevalier \& Lechevalier, 1980).

The detailed morphological, physiological and biochemical characteristics of strain $\mathrm{Y}_{3} 2^{\mathrm{T}}$ are given in the species description. A transmission electron micrograph showing the morphology of cells of strain $\mathrm{Y}_{3} 2^{\mathrm{T}}$ and a light micrograph showing endospores are available as supplementary figures (see Supplementary Figs S1 and S2, available in IJSEM Online). The phenotypic characteristics of strain $\mathrm{Y} 32^{\mathrm{T}}$ that showed that it was closely related to other species of the genus Pontibacillus and enabled it to be differentiated from phylogenetically related strains are presented in Table 1. The growth of strain $\mathrm{Y} 32^{\mathrm{T}}$ in media 
Table 1. Differential characteristics of strain $\mathrm{Y} 32^{\top}$ and other type strains of recognized species of the genus Pontibacillus

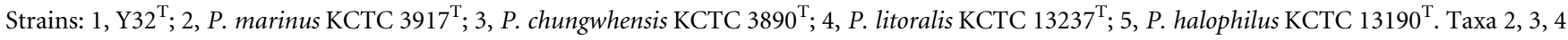
and 5 were the deposited strains as reported by Lim et al. (2005b), Lim et al. (2005a), Chen et al. (2010) and Chen et al. (2009), respectively. The experiments of all five strains were performed under the same laboratory conditions and the data are from this study. Cells of all strains are rod-shaped. +, Positive; -, negative; w, weakly positive; s, spherical, E, ellipsoidal; T, terminal; ST, subterminal.

\begin{tabular}{|c|c|c|c|c|c|}
\hline Characteristic & 1 & 2 & 3 & 4 & 5 \\
\hline Pigmentation & Yellow & Cream & Yellow & Creamy white & Yellow \\
\hline Spore shape & s & s & s & E & $\mathrm{E}$ \\
\hline Spore position & $\mathrm{T}$ & $\mathrm{T}$ & $\mathrm{T}$ & ST & ST \\
\hline $\mathrm{NaCl}$ range $(\%, \mathrm{w} / \mathrm{v})$ & $3-20$ & $1-9$ & $1-16^{*}$ & $0.5-15$ & $1-25$ \\
\hline $\mathrm{NaCl}$ optimum $(\%, \mathrm{w} / \mathrm{v})$ & $6-8$ & $2-5$ & $2-5$ & $2-5$ & $4-8^{\star}$ \\
\hline Oxidase & + & + & - & + & + \\
\hline Nitrate reduction to nitrite & + & + & - & + & - \\
\hline \multicolumn{6}{|l|}{ Hydrolysis of: } \\
\hline Aesculin & + & + & - & + & + \\
\hline Casein & - & - & + & - & - \\
\hline Gelatin & - & - & - & + & + \\
\hline Starch & + & - & + & - & + \\
\hline Tween 80 & - & + & + & - & - \\
\hline \multicolumn{6}{|l|}{ Acid production from: } \\
\hline D-Fructose & + & + & - & + & - \\
\hline D-Glucose & + & - & + & + & - \\
\hline Glycerol & - & - & + & - & - \\
\hline Maltose & + & + & + & + & - \\
\hline D-Mannitol & + & - & - & - & - \\
\hline D-Mannose & - & - & - & - & + \\
\hline Raffinose & - & + & - & - & - \\
\hline D-Ribose & - & + & + & - & + \\
\hline Sucrose & - & + & $+\dagger$ & + & - \\
\hline Trehalose & + & + & + & + & - \\
\hline \multicolumn{6}{|l|}{ Activity of: } \\
\hline Acid phosphatase & + & $-\dagger$ & $-\dagger$ & - & w \\
\hline Esterase (C4) & + & $+\dagger$ & $+\dagger$ & + & - \\
\hline$\alpha$-Chymotrypsin & $\mathrm{w}$ & $+\dagger$ & $+\dagger$ & - & - \\
\hline$\beta$-Galactosidase & - & $-\dagger$ & $+\dagger$ & - & - \\
\hline$\alpha$-Glucosidase & + & $+\dagger$ & $+\dagger$ & - & + \\
\hline$\beta$-Glucosidase & - & $-\dagger$ & $-\dagger$ & - & $\mathrm{w}$ \\
\hline$\beta$-Glucuronidase & - & $-\dagger$ & $-\dagger$ & - & + \\
\hline Leucine arylamidase & + & $\mathrm{w} \dagger$ & $+\dagger$ & + & - \\
\hline DNA $G+C$ content $(\mathrm{mol} \%)$ & 40.3 & 42.0 & 41.0 & 41.3 & 45.5 \\
\hline
\end{tabular}

${ }^{*}$ Data that were different from the results obtained in previous studies.

$\dagger$ Additional data from this study that have not been published in previous studies.

with all single sole carbon and nitrogen sources was negative. The length of $16 \mathrm{~S}$ rRNA gene sequence of strain $\mathrm{Y}^{2} 2^{\mathrm{T}}$ obtained was $1485 \mathrm{bp}$. The NCBI alignments indicated that strain $\mathrm{Y} 32^{\mathrm{T}}$ was closely related to P. marinus KCTC $3917^{\mathrm{T}}$ (97.8\% gene sequence similarity), P. chungwhensis $\mathrm{BH} 030062^{\mathrm{T}}(96.9 \%)$, P. litoralis JSM $072002^{\mathrm{T}}$ $(96.8 \%)$ and P. halophilus JSM $076056^{\mathrm{T}}(96.0 \%)$. Using the EzTaxon program, all the other gene sequence similarities, except for P. marinus, were below $97 \%$. Phylogenetic trees based on 16S rRNA gene sequences revealed that strain $\mathrm{Y} 32^{\mathrm{T}}$ fell within the branch of the genus Pontibacillus. The members of the genus Pontibacillus constituted an independent lineage in the phylogenetic trees using all three alignment methods (Fig. 1 and Supplementary Fig. S3a, b). In the neighbour-joining tree, strain $\mathrm{Y} 32^{\mathrm{T}}$ clustered with the clade comprising $P$. marinus and $P$. chungwhensis and the relationship between this cluster and $P$. litoralis was supported by bootstrap analysis at a confidence level of 75. The maximum-parsimony tree and maximum-likelihood tree showed that strain $\mathrm{Y} 32^{\mathrm{T}}$ and $P$. litoralis comprised a clade.

DNA-DNA relatedness between strain $\mathrm{Y}^{2} 2^{\mathrm{T}}$ and $P$. marinus KCTC $3917^{\mathrm{T}}$ was $42 \%$ (the range of values 


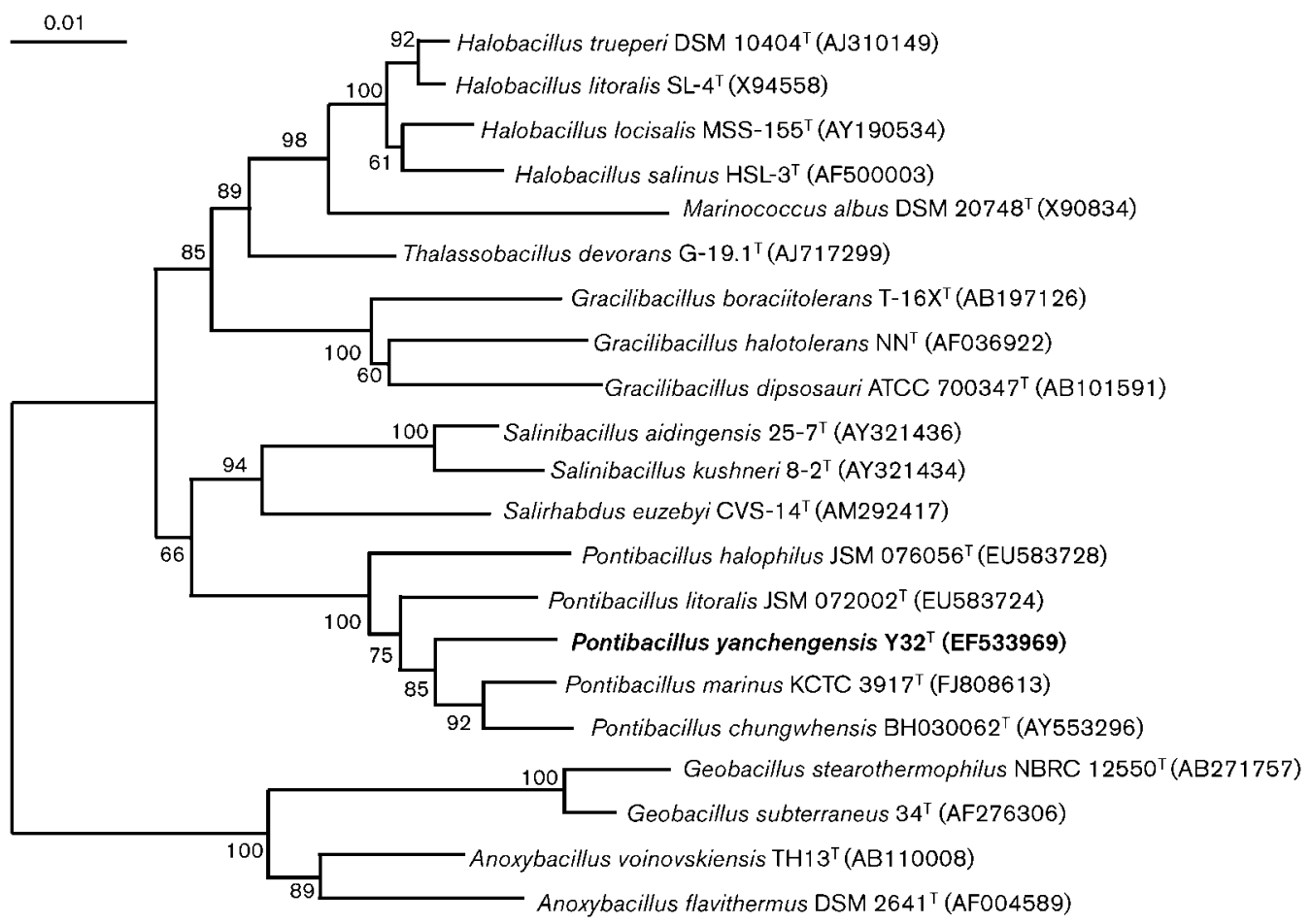

Fig. 1. A neighbour-joining tree based on 16S rRNA gene sequences showing the phylogenetic positions of strain $\mathrm{Y}_{32}{ }^{\top}$ and some related bacterial species. Numbers at branching nodes are bootstrap percentages from 1000 replications. Bar, $1 \%$ nucleotide substitution.

obtained in replicate assays was $41-42 \%)$. The DNA G + C content of strain $\mathrm{Y} 32^{\mathrm{T}}$ was $40.3 \mathrm{~mol} \%$. The novel strain possessed meso-diaminopimelic acid as the diagnostic diamino acid, which was in agreement with the description of genus Pontibacillus and with the properties of the majority of endospore-forming Gram-positive bacilli. Menaquinone 7 (MK-7) was the respiratory quinone. No minor quinone was detected. The major cellular fatty acids on MA plus $3 \%(\mathrm{w} / \mathrm{v}) \mathrm{NaCl}$ were anteiso- $\mathrm{C}_{15: 0}$, iso- $\mathrm{C}_{15: 0}$, iso- $\mathrm{C}_{16: 0}$, iso- $\mathrm{C}_{14: 0}$, anteiso- $\mathrm{C}_{17: 0}$ and $\mathrm{C}_{16: 1} \omega 7 c$ alcohol (see details in Table 2), which was in agreement with those of the type strains of the other recognized species of the genus Pontibacillus.

On the basis of distinctive physiological, morphological and other key traits of strain $\mathrm{Y}^{2} 2^{\mathrm{T}}$, it is concluded that the strain represents a novel species, for which the name Pontibacillus yanchengensis sp. nov. is proposed.

\section{Description of Pontibacillus yanchengensis sp. nov.}

Pontibacillus yanchengensis (yan.chen.gen'sis. N.L. masc. adj. yanchengensis of or belonging to Yancheng, as the type strain was isolated from a salt field in Yancheng).

Cells are Gram-positive-staining, rod-shaped (0.5$0.9 \times 1.9-2.5 \mu \mathrm{m})$, motile with flagella and are unable to grow in anaerobic conditions. Spherical endospores are formed at the terminal position in swollen sporangia. Colonies are yellow, smooth and have circular/slightly irregular margins after incubation on $\mathrm{MA}$ plus $5 \% \mathrm{NaCl}$ $(\mathrm{w} / \mathrm{v})$ at $37{ }^{\circ} \mathrm{C}$ for $48 \mathrm{~h}$. Grows in media containing 3-20\% (w/v) $\mathrm{NaCl}$; optimum growth occurs on media containing 6-8\% (w/v) $\mathrm{NaCl}$. No growth in the absence of $\mathrm{NaCl}$. Growth is observed at $\mathrm{pH}$ 6.0-9.5 and optimum growth occurs at $\mathrm{pH} 7.0-8.0$. The temperature range for growth is $15-45{ }^{\circ} \mathrm{C}$ (optimum, $35-40{ }^{\circ} \mathrm{C}$ ). Oxidase- and catalasepositive. Reduces nitrate to nitrite. Hydrolyses aesculin and starch, but not casein, L-tyrosine, Tween 80 , hypoxanthine, xanthine, gelatin or urea. Negative result in tests for the production of $\mathrm{H}_{2} \mathrm{~S}$ or indole, for the fermentation of glucose and for nitrite reduction. Negative result in methyl red and Voges-Proskauer tests. Produces acid from D-glucose, D-fructose, D-mannitol, maltose, trehalose and starch, but not from D-ribose, D-xylose, D-mannose, L-arabinose, L-rhamnose, $\alpha$-lactose, D-galactose, raffinose, D-salicin, melibiose, adonitol or sucrose. Enzyme activities are positive for alkaline phosphatase, esterase (C4), esterase lipase (C8), acid phosphatase, $\alpha$-glucosidase, naphthol-ASBI-phosphohydrolase and leucine arylamidase. Weak or negative activity for $\alpha$-chymotrypsin. Negative for lipase (C14), cystine arylamidase, $\beta$-glucuronidase, $\alpha$-fucosidase, $\alpha$-galactosidase, $\beta$-galactosidase, $N$-acetyl- $\beta$-glucosaminidase, lysine decarboxylase, $\alpha$-mannosidase, trypsin and valine arylamidase. Major cellular fatty acids on MA plus $3 \%(\mathrm{w} / \mathrm{v}) \mathrm{NaCl}$ are anteiso- $\mathrm{C}_{15: 0}$, iso- $\mathrm{C}_{15: 0}$, iso- $\mathrm{C}_{16: 0}$, 
Table 2. Whole-cell fatty acids of strain $\mathrm{Y} 32^{\top}$ and type strains of the genus Pontibacillus

Strains: 1 , Y32 ${ }^{\mathrm{T}}$; 2, P. chungwhensis KCTC $3890^{\mathrm{T}}$; 3, P. marinus KCTC $3917^{\mathrm{T}}$; 4, P. litoralis KCTC $13237^{\mathrm{T}}$; 5, P. halophilus KCTC $13190^{\mathrm{T}}$. All data are from this study. Cells of all strains used in the experiment were grown at $35{ }^{\circ} \mathrm{C}$ for 2 days on MA supplemented with $3 \%(\mathrm{w} / \mathrm{v})$ NaCl. -, Not detected.

\begin{tabular}{|c|c|c|c|c|c|}
\hline Fatty acid & 1 & 2 & 3 & 4 & 5 \\
\hline \multicolumn{6}{|c|}{ Straight-chain fatty acids: } \\
\hline $\mathrm{C}_{15: 0}$ & 1.0 & 0.7 & 0.5 & - & - \\
\hline $\mathrm{C}_{16: 0}$ & 1.0 & 2.5 & 1.0 & 1.0 & 0.8 \\
\hline \multicolumn{6}{|l|}{ Branched fatty acids: } \\
\hline iso- $\mathrm{C}_{14: 0}$ & 18.5 & 10.3 & 5.2 & 1.7 & 17.8 \\
\hline iso- $\mathrm{C}_{15: 0}$ & 25.2 & 23.9 & 68.9 & 63.8 & 48.5 \\
\hline anteiso- $\mathrm{C}_{15: 0}$ & 35.2 & 38.6 & 11.1 & 13.8 & 10.5 \\
\hline iso- $\mathrm{C}_{16: 0}$ & 5.1 & 6.9 & 3.1 & 2.5 & 7.6 \\
\hline iso- $\mathrm{C}_{17: 0}$ & 1.1 & 0.8 & 2.1 & 4.1 & 2.3 \\
\hline anteiso- $\mathrm{C}_{17: 0}$ & 4.1 & 5.7 & 1.8 & 0.7 & 2.1 \\
\hline iso- $\mathrm{C}_{17: 1} \omega 10 c$ & 0.3 & - & 0.6 & 6.8 & 0.8 \\
\hline \multicolumn{6}{|c|}{ Unsaturated fatty acids: } \\
\hline $\mathrm{C}_{16: 1} \omega 7 c$ alcohol & 6.2 & 8.3 & 3.3 & 1.8 & 6.8 \\
\hline $\mathrm{C}_{16: 1} \omega 11 c$ & 0.8 & 0.4 & 0.7 & 0.9 & 0.7 \\
\hline Summed feature $4^{\star}$ & 0.6 & 0.2 & 0.6 & 1.2 & 0.7 \\
\hline
\end{tabular}

${ }^{\star}$ Summed features are groups of two or three fatty acids that cannot be separated by GLC with the MIDI system. Summed feature 4 comprises iso- $\mathrm{C}_{17: 1} \mathrm{I}$ and/or anteiso- $\mathrm{C}_{17: 1} \mathrm{~B}$.

iso- $\mathrm{C}_{14: 0}$, anteiso- $\mathrm{C}_{17: 0}$ and $\mathrm{C}_{16: 1} \omega 7 c$ alcohol. The cell-wall peptidoglycan type is meso-diaminopimelic acid. The menaquinone is menaquinone-7 (MK-7).

The type strain, $\mathrm{Y} 32^{\mathrm{T}} \quad$ (=CGMCC $1.10680^{\mathrm{T}}=\mathrm{CCTCC}$ AB209311 ${ }^{\mathrm{T}}=$ NRRL B-59408 ${ }^{\mathrm{T}}$ ), was isolated from subsurface soil of Sanwei salt field, Yancheng, Jiangsu province, South-east China. The DNA G $+\mathrm{C}$ content of the type strain is $40.3 \mathrm{~mol} \%$ (HPLC).

\section{Acknowledgements}

We would like to thank Dr Jin-Woo Bae (Kyung Hee University) for purchasing P. marinus KCTC $3917^{\mathrm{T}}$ from the KCTC, the KCTC for providing the other three type strains, and Dr Chengxiang Fang (CCTCC, Wuhan University) for fatty acid analysis. This work was supported by the National Natural Science Foundation of China (30671140) and the Returning Overseas Scientist Fund of the Ministry of Education, P. R. China.

\section{References}

Ash, C., Farrow, J. A. E., Wallbanks, S. \& Collins, M. D. (1991). Phylogenetic heterogeneity of the genus Bacillus as revealed by comparative analysis of small-subunit-ribosomal RNA sequences. Lett Appl Microbiol 13, 202-206.

Cashion, P., Holder-Franklin, M. A., McCully, J. \& Franklin, M. (1977). A rapid method for the base ratio determination of bacterial DNA. Anal Biochem 81, 461-466.
Chen, Y.-G., Zhang, Y.-Q., Xiao, H.-D., Liu, Z. X., Yi, L.-B., Shi, J.-X., Zhi, X.-Y., Cui, X.-L. \& Li, W.-J. (2009). Pontibacillus halophilus sp. nov., a moderately halophilic bacterium isolated from a sea urchin. Int $J$ Syst Evol Microbiol 59, 1635-1639.

Chen, Y.-G., Zhang, Y.-Q., Yi, L.-B., Li, Z.-Y., Wang, Y.-X., Xiao, H.-D., Chen, Q.-H., Cui, X.-L. \& Li, W.-J. (2010). Pontibacillus litoralis sp. nov., a facultatively anaerobic bacterium isolated from a sea anemone, and emended description of the genus Pontibacillus. Int J Syst Evol Microbiol 60, 560-565.

Chun, J., Lee, J.-H., Jung, Y., Kim, M., Kim, S., Kim, B. K. \& Lim, Y. W. (2007). EzTaxon: a web-based tool for the identification of prokaryotes based on $16 \mathrm{~S}$ ribosomal RNA gene sequences. Int J Syst Evol Microbiol 57, 2259-2261.

Cowan, S. T. \& Steel, K. J. (1965). Manual for the Identification of Medical Bacteria. London: Cambridge University Press.

Dussault, H. P. (1955). An improved technique for staining red halophilic bacteria. J Bacteriol 70, 484-485.

Fairley, D. J., Boyd, D. R., Sharma, N. D., Allen, C. C. R., Morgan, P. \& Larkin, M. J. (2002). Aerobic metabolism of 4-hydroxybenzoic acid in Archaea via an unusual pathway involving an intramolecular migration (NIH shift). Appl Environ Microbiol 68, 6246-6255.

Felsenstein, J. (2002). PHYLIP (phylogeny inference package), version 3.6a. Distributed by the author. Department of Genome Sciences, University of Washington, Seattle, USA.

Huß, V. A. R., Festl, H. \& Schleifer, K. H. (1983). Studies on the spectrophotometric determination of DNA hybridization from renaturation rates. Syst Appl Microbiol 4, 184-192.

Lányí, B. (1987). Classical and rapid identification methods for medically important bacteria. Methods Microbiol 19, 1-67.

Lechevalier, M. P. \& Lechevalier, H. A. (1980). The chemotaxonomy of actinomycetes. In Actinomycete Taxonomy (Special Publication no. 6), pp. 227-291. Edited by A. Dietz \& J. Thayer. Arlington, VA: Society for Industrial Microbiology.

Leifson, E. (1963). Determination of carbohydrate metabolism of marine bacteria. J Bacteriol 85, 1183-1184.

Lim, J.-M., Jeon, C. O., Song, S. M. \& Kim, C.-J. (2005a). Pontibacillus chungwhensis gen. nov., sp. nov., a moderately halophilic Grampositive bacterium from a solar saltern in Korea. Int J Syst Evol Microbiol 55, 165-170.

Lim, J.-M., Jeon, C. O., Park, D.-J., Kim, H.-R., Yoon, B.-J. \& Kim, C.-J. (2005b). Pontibacillus marinus sp. nov., a moderately halophilic bacterium from a solar saltern, and emended description of the genus Pontibacillus. Int J Syst Evol Microbiol 55, 1027-1031.

Logan, N. A., Berge, O., Bishop, A. H., Busse, H.-J., De Vos, P., Fritze, D., Heyndrickx, M., Kämpfer, P., Rabinovitch, L. \& other authors (2009). Proposed minimal standards for describing new taxa of aerobic, endospore-forming bacteria. Int J Syst Evol Microbiol 59, 2114-2121.

Mata, J. A., Martínez-Cánovas, J., Quesada, E. \& Béjar, V. (2002). A detailed phenotypic characterisation of the type strains of Halomonas species. Syst Appl Microbiol 25, 360-375.

Nielsen, P., Rainey, F. A., Outtrup, H., Priest, F. G. \& Fritze, D. (1994). Comparative $16 \mathrm{~S}$ rDNA sequence analysis of some alkaliphilic bacilli and the establishment of a sixth rRNA group within the genus Bacillus. FEMS Microbiol Lett 117, 61-66.

Smibert, R. M. \& Krieg, N. R. (1994). Phenotypic characterization. In Methods for General and Molecular Bacteriology, pp. 607-654. Edited by P. Gerhardt, R. G. E. Murray, W. A. Wood \& N. R. Krieg. Washington, DC: American Society for Microbiology.

Tamaoka, J. \& Komagata, K. (1984). Determination of DNA base composition by reversed-phase high-performance liquid chromatography. FEMS Microbiol Lett 25, 125-128. 
Tamura, K., Dudley, J., Nei, M. \& Kumar, S. (2007). MEGA4: Molecular evolutionary genetics analysis (MEGA) software version 4.0. Mol Biol Evol 24, 1596-1599.

Thompson, J. D., Higgins, D. G. \& Gibson, T. J. (1994). CLUSTAL W: improving the sensitivity of progressive multiple sequence alignment through sequence weighting, position-specific gap penalties and weight matrix choice. Nucleic Acids Res 22, 4673-4680.

Ventosa, A., Nieto, J. J. \& Oren, A. (1998). Biology of moderately halophilic aerobic bacteria. Microbiol Mol Biol Rev 62, 504-544.
Ventosa, A., Quesada, E., Rodriguez-Valera, F., Ruiz-Berraquero, F. \& Ramos-Cormenzana, A. (1982). Numerical taxonomy of moderately halophilic Gram-negative rods. J Gen Microbiol 128, 1959-1968.

Wilson, K. H., Blitchington, R. B. \& Greene, R. C. (1990). Amplification of bacterial $16 \mathrm{~S}$ ribosomal DNA with polymerase chain reaction. J Clin Microbiol 28, 1942-1946.

Xie, C. H. \& Yokota, A. (2003). Phylogenetic analyses of Lampropedia hyalina based on the 16S rRNA gene sequence. J Gen Appl Microbiol 49, 345-349. 